\title{
The impact of economic expectation, social capital and hope on migration request and action
}

\author{
Şerafettin Keleş ${ }^{1}$ (D) \\ 1 Asst. Prof. Dr., Erzincan University, Faculty of Economics and Administrative Sciences, Department of Economics, Erzincan, TURKEY \\ E-mail: skeles2580@gmail.com
}

\begin{abstract}
In this study, the factors affecting the request and action of migration are examined with empirical method within the scope of neoclassical economic theories and behavioral economic thought. A survey of a selected sample was analyzed with structural equation modeling. There was a linear relationship between migration and economic expectation, social capital and hope. It was found that the Economic Expectation Variable had a very strong negative effect on individuals' decision to immigrate and desire to migrate $(\gamma=-0.99 ; \mathrm{t}=-17.87)$. Hope variable has a very strong negative effect on individuals' migration decision and desire to migrate $(\gamma=-0.96 ; \mathrm{t}=-13.66)$. The Social Capital Secret Variable has a negatively moderate effect on individuals' decision to immigrate and desire to migrate $(\gamma=-0.48 ; \mathrm{t}=-8.19)$. It was seen that economic and political conjuncture was effective in the decision of migration of individuals.
\end{abstract}

Keywords: Economic Impact, Hope, Social Capital, Behavioral Economics, Migration

JEL codes: A12, B55, C25, E71, F22 


\section{INTRODUCTION}

Although migration as far back as human history dates back to many social, political, economic, ecological and cultural reasons, it basically refers to the temporary or permanent transfer of individuals from one geographical region to another as a result of the effort to survive (Hagen-Zanker, 2008). The fact that the act of migration took place for different reasons has led to the different criteria and approaches of the different disciplines to be addressed and thus many different theories and models emerged (Massey et al., 1993).

The event of migration is also in the field of economics which is a social science. In economic science, the migration phenomenon is analyzed by economic theories and models. In neoclassical economic theory, migration is explained as part of economic development. Migrants often arise as a result of geographical differences between the traditional agricultural sector in rural areas and the modern manufacturing sector in urban areas, resulting from labor supply and demand. The fact that the rural economy is based on agriculture causes labor supply surplus. In urban economies, the intensity of industry and service sectors increases the demand for labor, and the relatively high wage pushes the excess supply of labor in rural areas to meet the demand for labor in urban areas, thus inter-regional dual labor market constitutes economic theories and models of migration (Lewis, 1954; Harris \& Todaro, 1970).

In particular, the mechanization of the agricultural sector causes some labor to remain idle and creates a surplus of labor in the traditional agricultural sector. The surplus of labor, that is, rural agricultural workers, is affected by the positive wage gap in the urban area and migrates to or withdraws from the urban production sectors. Migration continues until wage equalization between rural and urban (Lewis, 1954; Ranis \& Fei, 1961). However, the increase in population density in cities increases urban unemployment over time. The rapid growth of the urban population puts immigrants at risk. Because rural migrants may not find work. In this case, rural to urban migration occurs as long as the expected real income difference is positive. Expected income is often fixed by law (minimum wage) and urban employment is limited. As such (ceteris paribus) migration increases if urban wages increase or the employment rate of cities increases (Todaro, 1969; Harris \& Todaro, 1970).
One of the theories of economic migration is the system model as a dynamic and spatial process. In addition to social and economic conditions, many factors such as government policies, transportation and communication infrastructure, changes in family and social values, and the publication and announcement of employment agencies are effective in individuals' decision to migrate. This system has a dynamic functioning and makes migration permanent (Mabogunje, 1970).

In the researches, it is claimed that economic factors such as wages as well as non-economic factors are effective in the migration decisions of individuals (Deller et al., 2001; Oehmke et al., 2007; Michaelides, 2011; Hotchkiss \& Rupasingha, 2018). These noneconomic factors include social and cultural opportunities, environmental quality, and quality of life, which provide individuals with the hope of a better life. The most recent addition to these noneconomic factors is social capital (Kan, 2007; David, 2010).

Individuals' hopes about the future along with economic concerns in the migration decision make them to make an informed decision about migration and to make cognitive decisions (Crawford, 1973). Hopes for the future, being rich, living in better conditions, good education, art, culture and realization of dreams are certain material and spiritual goals. Although targets are often rational, they carry emotional and psychological elements and are subjective (HagenZanker, 2008). The factors that initiate the migration and the conditions that cause the migration to continue can be different. After the pioneering migration, the emigration of the survivors imitates the migrants, and the migration becomes continuous. Social networks and relationships, that is, social capital, lead to continuity of migration (Massey, 1990).

Mutual recognition each of the individual and long formed as a result of ongoing relationships of friendship, trust and the sum of an individual or community accrued resources by having to loyaltybased network of relationships are defined as social capital (Bourdieu \& Wacquant,1992). Social capital, which expresses people's relations with other people, turns into a benefit and productive activity for individuals when it is used to achieve a goal (Coleman, 1988). In other words, social capital functions as the point of contact of the source of information and opportunity for individuals (Adler \& Kwon, 2002). 
The economy deals with predictions for the future. In the light of their past experiences, individuals have the expectation and orientation to live a better life in the future. The tendencies and expectations that have emerged over time can be made up of individual aspirations that serve as leverage to go beyond difficult living conditions (Narotzky \& Besnier, 2014). For example, "land and stone of Istanbul is gold " business for society as a whole, is also the location for individuals seeking a better future of hope and prosperity as it expresses. But the dream of a better future can be expressed in other ways. With new economic models, growth and optimal allocation of resources across the country can give individuals the opportunity to live their dreams without migrating. In practice, these economic models need to be put into projects to make life better for future generations. But, of course, "better" depends on time and space and expresses "a hope" (Narotzky \& Besnier, 2014).

It is stated that the "hope theory" developed in the field of Behavioral Economics (Kahneman \& Tversky, 1979; Tversky \& Kahneman, 1991). did not find much application in the process of migration decision making (Czaika, 2015). The migration economy is still explained by neoclassical models (Sjaastad, 1962; Todaro, 1969; Harris \& Todaro 1970). Neoclassical economic migration decisions, (expected) wages, income and other economic opportunities, social networks, social capital, human capital, risks and uncertainties are argued to be effective (Massey et al., 1993; Massey et al., 1999). Individuals also take into account risks and uncertainties when deciding to emigrate. Immigrants are rational, as predicted by the expected benefit theory, but they like risk, but try to reduce the cost of risk by diversifying and diversifying work among family members for subsequent risks (Sahota, 1968; Simon, 1983; Katz \& Stark, 1986). However, migration options may include behavioral anomalies, which often lead to irrational decisions (Kahneman et al., 1991). The standard neoclassical (economic) migration model based on the expected utility theory and the "hope theory" will be richer and inclusive (Czaika, 2015).

Migration decisions are made under uncertainty and risk. Information about the future is lacking and it is unpredictable whether migration will bring success or failure for individuals. If the migration decision is considered as an investment project for individuals, the realization of this project for the benefit of individuals depends on the knowledge and expectations about the future (Czaika, 2015). Individuals act in accordance with the latest changes in their minds about the current and future economic situation in their hometown and where they wish to emigrate when they decide to leave or return. Bad news about the general economic situation and unemployment in the future are more impressive than good news, and migration flows are affected. If the economic situation at the target location matches the individual's expectations, the decision is made for migration (Kahneman \& Tversky, 1979).

Expected utility theory and rational choice paradigm confront behavioral economics and limited rationality (Simon, 1983). According to the expected utility theory, individuals avoid losses. However, individuals risk higher risks for higher earnings. Contrary to the expected utility theory, individuals' choice between some alternative economic or monetary outcomes is often framed as (relative) gains or losses based on a reference point. Absolute linear independent behavioral models based on the expected benefits from the reference to the probability, that is not dependent on a result of evaluation of existing structures or any other reference point. The preferences of individuals can be reversed due to framing the results as gain or loss (Tversky \& Kahneman 1991). If the economic situation deteriorates in the country, the possibility of not finding a job that decreases from $95 \%$ to $90 \%$ or finding a job that increases from $5 \%$ to $10 \%$ according to the possibility of finding a job or protecting the current job is framed and perceived negatively. According to the expected utility theory and neoclassical model, information should not be affected by behavioral reaction due to rational evaluation and framing. Individuals frequently revise the information that will be represented as gain or loss by referring to a reference point rather than focusing on absolute results (Mercer, 2005; Czaika, 2015). In case of exceeding the reference point, that is the position or target to be achieved, the pleasures and pleasures increase, but in case of loss, the pain becomes more. An equivalent loss is more painful than an equivalent gain (Tversky \& Kahneman, 1991).

However, it has been experimentally proven that individuals sometimes make irrational choices for gaining reputation or status, taking into account potential further losses in the future (Kahneman \& Tversky, 1979; Kahneman et al., 1991). Therefore, individuals' hopes of making significant gains from migration cause them to take equal or greater losses. Again, in spite of lucrative migration opportunities, individuals may give up migration due to sunken 
costs within the scope of rational choice theory. The acquisition of a new skill and status instead of an acquired skill and status requires a cost (Thaler, 1980). Similarly, the costs and regrets to be incurred as a result of a wrong migration choice also affect the migration decisions.

This study aims to provide an integrated analysis of the effects of economic expectations, hope and social capital on the potential migration idea and the desire for actual migration within the scope of neoclassical economic migration theories, expected utility theory, rational choice paradigm, behavioral economics and limited rationality. The microeconomics-based study measures the impact of the economic and social situation in the country on immigration decisions on immigrants and provides information and ideas to the literature and related parties.

\section{MATERIALS AND METHODS}

\subsection{Materiel}

In the study, a Structural Equation Modelling was based on the literature on neoclassical migration theories and behavioral economics. In the Structural Equation Modelling, horizontal cross-sectional data obtained from surveys conducted in 2018 with rural individuals living in rural settlements of the central district of Erzincan were used as the study material. The analysis of the model was performed with LISREL 8.72 and SPSS 21 package programs.

\subsubsection{Determination of Sample Size}

The total population in rural settlements of Erzincan central district is 18730 people (Anonymous, 2018a). Random sampling method was preferred and the number of questionnaires was calculated by Yamane (1967) formula.

In the formula, $\mathrm{n}=$ sample size, $\mathrm{N}=$ settlement population, $\mathrm{P}=$ those who want migration, $\mathrm{Q}=$ those who do not want migration, $Z=\%(1-\alpha) Z$ test value, $\alpha=$ significance level, $\mathrm{d}=$ error (tolerance) share. $\mathrm{Z}$ Confidence coefficient $95 \%$ confidence coefficient, 1,96. The ratio of those who want to migrate to work with large samples was taken as 0.5 and the sample size was calculated as 280 .

\subsubsection{Preparation of Survey Questions and Analysis Process}

The questionnaire questions were originally created within the scope of neoclassical economic migration theories, expected utility theory, rational choice paradigm, behavioral economics and limited rationality. The economic expectations of the individuals, the questions of hope and social capital were prepared by utilizing the theoretical studies presented in the introduction part of the study. Demographic information was obtained from open-ended questions. They were asked in the form of questions to show the potential of migrating from rural areas to cities. The answer is yes and no. The other question is likertscale. The questions of economic expectation, hope and social capital were scaled with likert method 1 strongly disagree, 2 disagree, slightly agree 3, agree 4, strongly agree 5 points. The study was carried out with Structural Equation Modeling analyzes.

\subsection{Model}

\subsubsection{Structural Equation Model}

Structural equation models are used to test the relationships between observed and latent variables (Jöreskog \& Sörbom, 1993) in order to measure a certain theoretical relationship in many different disciplines (Bentler \& Yuan, 1999; Cheung \& Rensvold, 2002; Raykov \& Marcoulides, 2006) is frequently used (Hoyle, 1995; Leech et al., 2005; Ilhan \& Cetin, 2014). Structural equation models (Hershberger, 2003), taking into account the measurement errors and deficiencies of the variables observed differently from the traditional econometrics measurement methods allow it to be used extensively in many different areas (Lomax \& Schumacker, 2004; Pituch \& Stevens, 2009). Another reason is that it can show indirect and direct effects among variables and allows multivariate model development, estimation and testing.

The subject of the study is the structures and relationships that cause the migration demand from rural to urban areas. Immigration will and action were evaluated in the long and short term. In the long term, individuals subconscious minds of potential immigration or the prospect of better immigration when the economic situation deteriorates were directly asked: 'Would you like to migrate to the city center or another city?' Participants were asked to answer yes or no and were scaled with [Yes 2, No 1]. In the short term, the request for migration has been considered depending on the current economic and social conditions and the question 'I am thinking of emigrating from the village now' was asked as a five-point Likert. In the fictionalized model, the "immigration request and action in of the individuals living in rural areas and agricultural workers to big 
cities was measured. Internal latent variables of the model; economic expectation from migration, hope and social capital The theoretical model is shown in Figure 1 below.

Figure 1. Factors Affecting Migration Decision

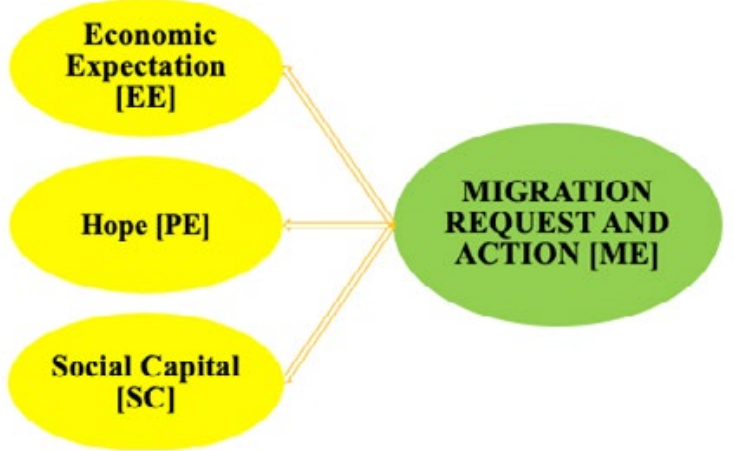

\subsection{Scales of the Model}

\subsubsection{Immigration Request and Action}

The phenomenon of migration is distinguished by conservative and innovative qualities. Innovative migration refers to migration to reach a life in line with new goals; conservative migration is defined as a transfer to those areas that offer better opportunities to get rid of deteriorating living conditions and falling standards of living at the place of residence (Petersen, 1958). Internal migration in Turkey is generally conservative (Bıçk1, 2011). Individuals living in rural areas want to migrate to big cities because of the "attractive" features of urban life. The desire of individuals to immigrate is not only for themselves but also for the family to provide a better standard of living. Rural migrants prefer places with developed industrial and service sectors, with strong social and physical infrastructure and labor needs (Balcıoğlu, 2007). "Request and Action for Migration" was considered to be long and short term. In the long run, the request for immigration and action was considered as a desire independent of economic, social and psychological factors. The desire to emigrate in the short term was accepted as a dynamic decision affected by economic, social and motivational factors. The scale consists of two questions. Participants are asked to answer the first question as yes or no. The second question is a five-point Likert structure. Survey questions and icons are below.

MT - Would you like to migrate to the city center or another city?

MD - I'm thinking of emigrating from the village now.

\subsubsection{Economic Expectation}

Economic factors play an important role in determining attitudes towards migration. In times of economic hardship and crisis, those who want to emigrate are worried about finding a job. Research has confirmed that economic concerns lead to negative attitudes on migrants, both correlationally and mentally (Esses et al., 2010). Both the immigrants and the society where they want to migrate tend to exhibit negative attitudes towards immigrants (Esses et al., 2003). The relationship between economic expectation and migration was measured by the following survey questions. The scale questions are five-point likert. Survey questions and icons are below.

EC1 Living in the city is easier.

EC3 The welfare level in the city is high.

EC6 The city will have make more economic and social contributions to me and my family.

EC8 I would like to take advantage of the city's business and work opportunities.

EC10 Good living conditions in the city.

\subsubsection{Hope}

The opportunities and constraints between individuals' hometown and the new settlements they want to migrate are expressed as attractive and repulsive factors on the desire for migration. Attractive factors are the facilitators and new opportunities that enable individuals to make decisions in favor of migration. These factors motivate individuals in migration decision. The driving factors are various negative factors, including complicating and exclusionary factors (Zafer, 2016). Immigrants pursue hopes such as a better life, a better environment, more income and a higher level of prosperity. The following scale questions are five-point likert. Survey questions and icons are below.

PS1 - It will not be difficult for me to leave my village PS2 - In my opinion, there is a life in the city close to my ideals.

PS3 - I hope that I will be pleased with my life in the city I will emigrate to.

PS4 - My life in the city I will migrate will change positively over time.

PS6 - If I migrate to the city, I will not worry about the future. 


\subsubsection{Social Capital}

The effect of social capital on migration has been examined in different studies. In the context of binding social capital, family ties have different effects on migration decision (Spilimbergo \& Ubeda, 2004). Individuals can access social capital through membership in social networks and social institutions and convert their social capital into forms of capital to improve their position in society (Coleman, 1988; Bourdieu, 1989). Social networks are a set of interpersonal networks that connect through kinship, friendship, and citizen-based relationships. Network connections increase the likelihood of migration. Because the costs and risks of moving through social networks are decreasing and the expected net returns for migration are increasing. The bonds established by the immigrants provide an important transfer of financial capital, that is, savings in abroad and the opportunity to send money home (Palloni et el., 2001). Social capital is effective in individuals' migration decision. The following social capital scale questions have a five-point likert structure.

B1 - I have a strong connection with my relatives in the city.

B2 - I care about my relatives in the city.

B4 - I often meet with relatives and friends in the city.

B6 - I trust relatives and friends.

BR1 - People are generally honest and trustworthy.

\section{RESULTS AND DISCUSSION}

\subsection{Demographic and Socioeconomic Findings}

Demographic and sociocultural characteristics of the individuals who participated in a face-to-face survey in the rural area of Erzincan are given below. Given the assumption that there will be a relationship between the ages of individuals and immigration and social capital, importance was given to conducting surveys with individuals from all age groups. The following Table 1shows the age groups and percentage distribution of the individuals surveyed.

Table 1: Age distribution of participants

\begin{tabular}{|l|c|c|c|c|c|c|}
\hline \multicolumn{1}{|c|}{ Age Range } & $\mathbf{2 5 - 2 9}$ & $\mathbf{3 0 - 3 5}$ & $\mathbf{3 6 - 4 5}$ & $\mathbf{4 6 - 6 0}$ & $\mathbf{6 1}$ and over & Total \\
\hline Frequency & 31 & 59 & 66 & 66 & 58 & 280 \\
\hline The ratio $\%$ & 11,1 & 21,1 & 23,6 & 23,6 & 20,7 & 100,0 \\
\hline
\end{tabular}

Source: Original calculations.

In rural migration surveys, it was taken into consideration that there is a relationship between the educational status of individuals and migration from each education group. The educational level of the participants is given in the Table 2 (below). $26.8 \%$ of the participants are primary, $28.9 \%$ are secondary, $25.0 \%$ are high school, $2.5 \%$ are associate degree and $16.8 \%$ are undergraduate.

Table 2. Training of Participants

\begin{tabular}{|l|c|c|c|c|c|c|}
\hline Graduated School & $\begin{array}{c}\text { Primary } \\
\text { School }\end{array}$ & $\begin{array}{c}\text { Secondary } \\
\text { School }\end{array}$ & High School & $\begin{array}{c}\text { Associate } \\
\text { Degree }\end{array}$ & Faculty & Total \\
\hline Frequency & 75 & 81 & 70 & 7 & 47 & 280 \\
\hline The ratio $\%$ & 26,8 & 28,9 & 25,0 & 2,5 & 16,8 & 100 \\
\hline
\end{tabular}

Source: Original calculations. 
It is known that the income level of the families is an important factor in the migration decision of the rural people. Table 3 below shows the total family income levels of the participants. Monthly total family income levels of the participants were found to be $2.1 \%$ between $\$ 150$ - $\$ 250,17.9 \%$ between $\$ 251-\$ 400,60.4 \%$ between $\$ 401-\$ 500$, $16.1 \%$ between $\$ 501-\$ 600$ and $3.6 \%$ above $\$ 601$.

Table 3. Monthly Total Family Income of the Participants

\begin{tabular}{|c|c|c|c|c|c|c|}
\hline $\begin{array}{l}\text { Rural Family } \\
\text { Income }\end{array}$ & $\begin{array}{c}\$ 150-\$ \\
250\end{array}$ & $\begin{array}{l}\$ 251- \\
\$ 400\end{array}$ & $\begin{array}{l}\$ 401- \\
\$ 500\end{array}$ & $\begin{array}{l}\$ 501- \\
\$ 600\end{array}$ & $\begin{array}{c}\text { above } \$ \\
601\end{array}$ & Total \\
\hline Frequency & 6 & 50 & 169 & 45 & 10 & 280 \\
\hline The ratio $\%$ & 2,1 & 17,9 & 60,4 & 16,1 & 3,6 & 100,0 \\
\hline
\end{tabular}

Source: Original calculations

\subsection{Results of Structural Equation Modeling}

The data obtained from the survey were analyzed with SPSS 21 statistical package program and Lisrel 8.72 package program. The means, standard deviations and reliability tests of the data were performed with SPSS 21 package program. Cronbach's Alpha coefficient was calculated as the most widely used method for reliability tests. Afterwards, Structural Equation Modeling analysis was performed with Lisrel 8.72 package program and standardized factor load values and $t$ values of the observed variables were calculated. The following Table 4 shows the calculations of the observed variables.

Table 4. Calculations of Observed Variables

\begin{tabular}{|c|c|c|c|c|c|}
\hline $\begin{array}{l}\text { Observed } \\
\text { Variables }\end{array}$ & Mean & $\begin{array}{l}\text { Standard } \\
\text { Deviation }\end{array}$ & $t$ value & $\begin{array}{c}\text { Standardized Factor Load } \\
\text { Values }\end{array}$ & Cronbach's Alpha Value \\
\hline \multicolumn{6}{|c|}{ Migration Request And Action (ME) } \\
\hline $\mathrm{MD}$ & 1.24 & 0.427 & 22.17 & 0.97 & 0.875 \\
\hline MT & 3.90 & 1.526 & -20.17 & -0.92 & 0.832 \\
\hline \multicolumn{6}{|c|}{ Economic Expectation (EE) } \\
\hline EC1 & 3.87 & 1.311 & 18.12 & 0.86 & 0.835 \\
\hline EC3 & 4.78 & 0.605 & 10.10 & 0.56 & 0.854 \\
\hline EC6 & 4.34 & 1.229 & 20.24 & 0.92 & 0.835 \\
\hline EC8 & 4.21 & 1.398 & 22.44 & 0.98 & 0.831 \\
\hline EC10 & 4.43 & 3.174 & 4.65 & 0.28 & 0.897 \\
\hline \multicolumn{6}{|c|}{ Hope (PE) } \\
\hline PS1 & 3.16 & 1.232 & 14.02 & 0.72 & 0.842 \\
\hline PS2 & 3.91 & 1.287 & 21.86 & 0.96 & 0.832 \\
\hline PS3 & 3.96 & 1.325 & 22.78 & 0.98 & 0.831 \\
\hline PS4 & 3.90 & 1.326 & 22.52 & 0.98 & 0.831 \\
\hline PS6 & 1.73 & 0.979 & -5.43 & -0.32 & 0.875 \\
\hline \multicolumn{6}{|c|}{ Social Capital (SC) } \\
\hline B1 & 3.93 & .977 & 20.08 & 0.96 & 0.848 \\
\hline B2 & 4.29 & .806 & 14.96 & 0.79 & 0.854 \\
\hline B4 & 3.43 & .818 & 10.73 & 0.60 & 0.851 \\
\hline B6 & 3.93 & .935 & 8.62 & 0.50 & 0.861 \\
\hline BR1 & 1.75 & 1.003 & 4.45 & 0.27 & 0.860 \\
\hline
\end{tabular}

Chi-Square $=347.69 \quad \mathrm{DF}=116 \quad \mathrm{P}$-value $=0.00000 \quad$ RMSEA $=0.085$

Source: Original calculations. 
Since the $t$ values of the observed variables in the model were greater than \pm 1.96 , it was found to be statistically significant at 5\% significance level. Chi-square / degree of freedom (Chi-Square / DF), p-value and RMSEA (Rootmean-square error approximation) were used as the measurement criteria used to evaluate the agreement between data and model. $X^{2} / d f(347.69$ / 116) for the model was calculated as 2.99. This value is within the acceptable values of five and less than five. Likewise, the RMSEA value is within acceptable limits (0.085). Since the model had a $p$ value of $<0.0000$, it was statistically significant at $5 \%$ significance level.

The structural model shows explanatory relationships between latent variables (Raykov \& Marcoulides, 2006). In other words, the structural model is used to test the relationships between latent variables (Weston \& Gore, 2006). Structural equation modeling includes observed and latent variables together and latent variables are defined by observed variables (Kahn, 2006; Tabachnick et al., 2007). Inclusion of dependent and independent variables constitutes the direction of canonical correlation and the definition of causal relationships between variables constitutes the direction of regression analysis (Tabachnick et al., 2007). In the structural equation model shown in Figure 1 below, standardized values (regression values) are given. The model shows the structural relationships between rural individuals' desire to emigrate in the short and long term and economic expectation, hope and social capital.

Figure 1. Structural Equation Model and Standardized Coefficients

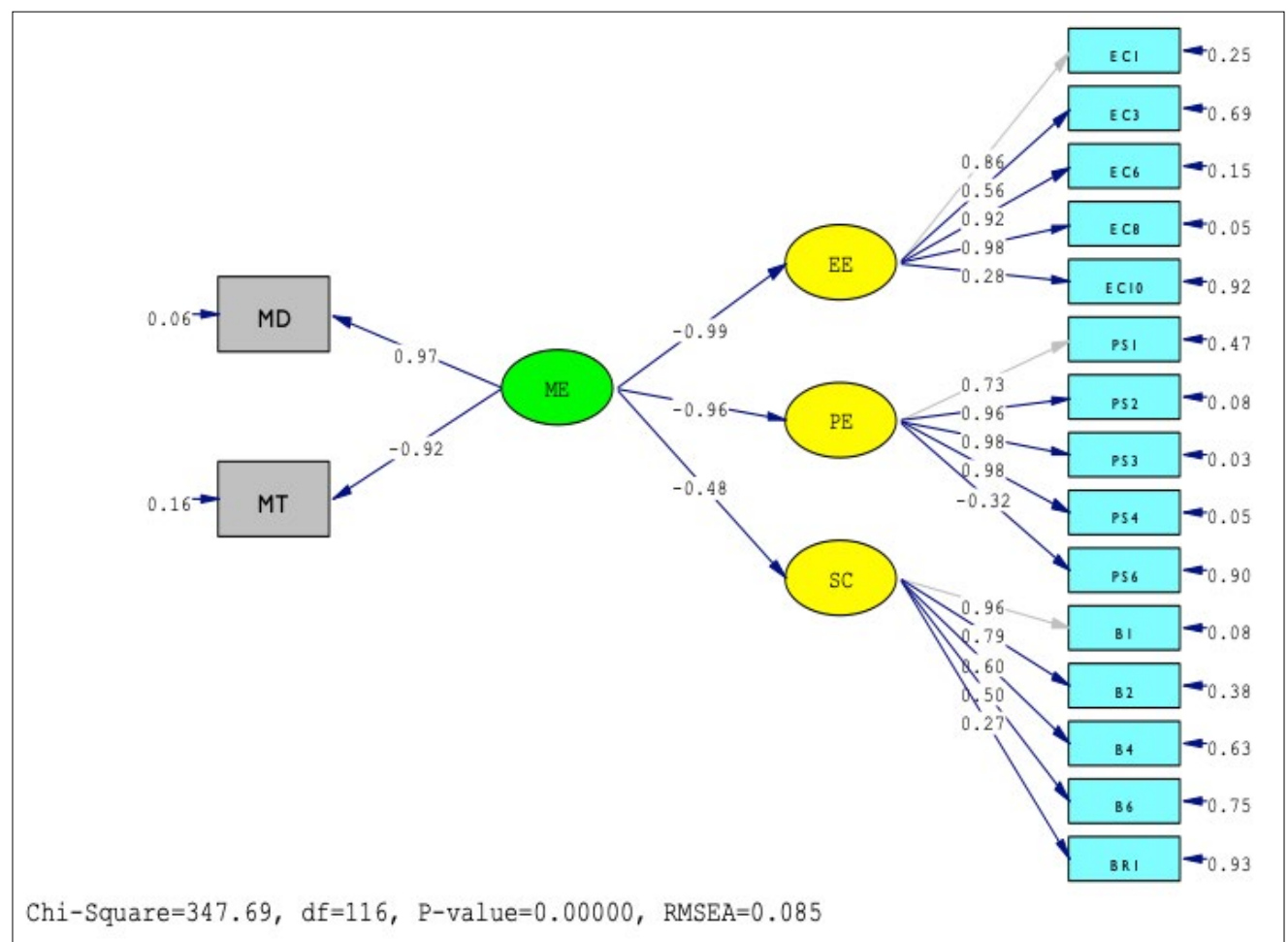

In Figure 2, rural migration structural model $t$ values are given according to their dimensions. Accordingly, Economic Expectation $(t=-17.87)$, Hope $(t=-13.66)$, Social Capital $(t=-8.19)$ were found to be statistically significant at $5 \%$ significance level, respectively. 
Figure 2. Structural Equation Model t values

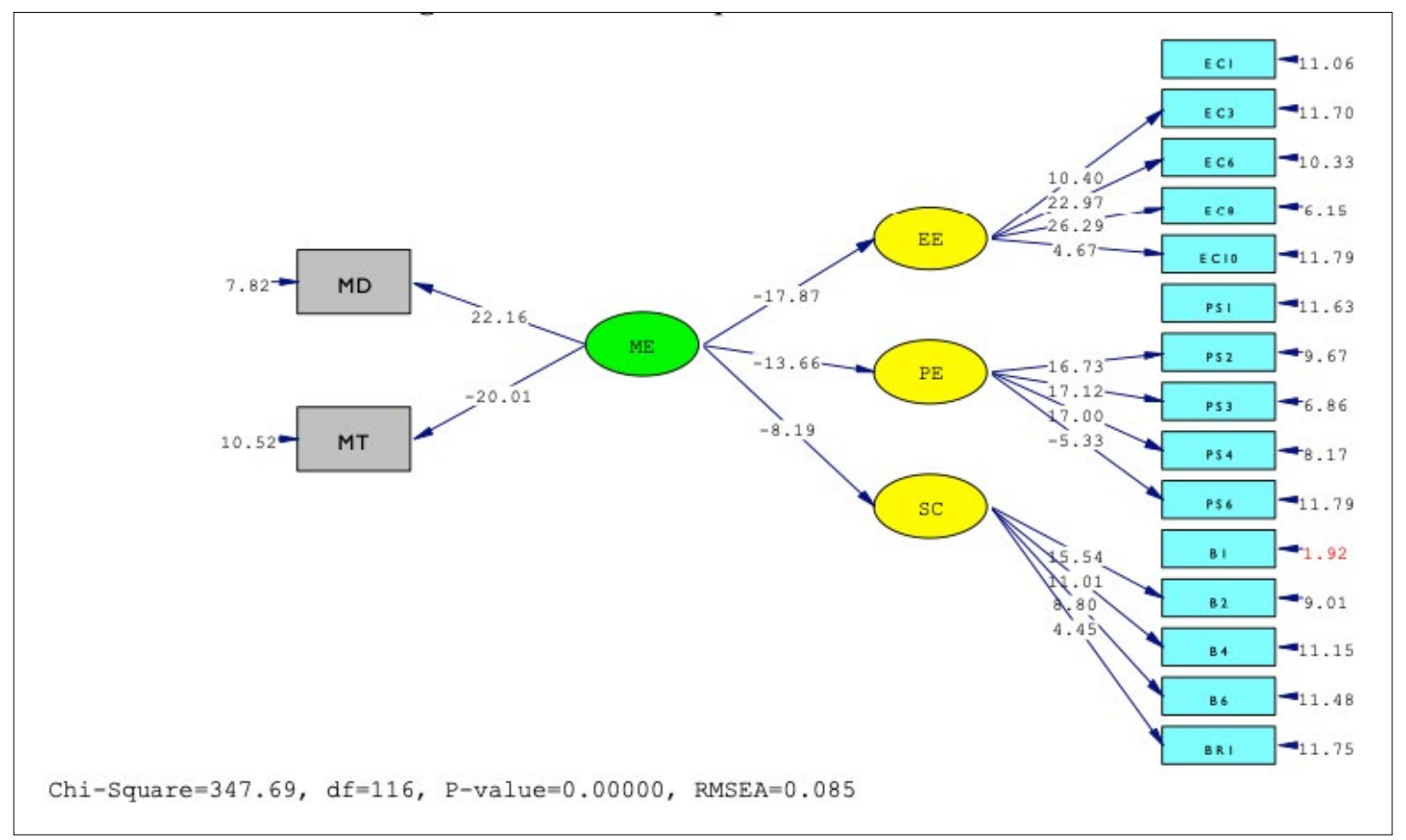

Migration Request And Action (ME) was seen as long-term emotional and short-term rational behavior. $76.1 \%$ of the participants answered "Yes" to the question in "MD - Would you like to migrate to the city center or another city?". According to Structural Equation Modeling, MD $(\gamma=0.97$ and $t=22.16)$ values were found. The economic and political conjuncture was highly influential "MT - I am thinking of migrating from the village now." Likert scale was asked and the result of the model, $\mathrm{MT}(\gamma=-0.92$ and $t=-20.01)$ was found. All parameters (latent variables $)$ in the model have a negative effect on this result.

“Economic Expectation (EE)"latent variable has a strong impact on the negative direction of individuals' decision to migrate and their desire to migrate $(\gamma=-0.99 ; \mathrm{t}=-17.87)$. The most important observed variables of latent variable are "EC6 - The city will have more economic and social contribution to me and my family." and "EC8 - I would like to take advantage of the city's business and work opportunities.

"Hope (PE)" latent variable on migration decisions of individuals $(\gamma=-0.96 ; t=-13.66)$ has a negative effect is very strong. The most important observed variables of latent variable are; "PS3 - I hope that I will be pleased with my life in the city I will emigrate to." and "PS4 - My life in the city I will migrate will change positively over time."

"Social Capital (SC)" latent variable has a negatively moderate effect on individuals' decision to immigrate and desire to migrate $(\gamma=-0.48 ; \mathrm{t}=-8.19)$. The most important observed variables of latent variable are; "B1 - I have a strong connection with my relatives in the city." and "B2 - I care about my relatives in the city."

Whether the data set confirms the theoretical structure to be tested is determined using the indexes of fit (Pedhazur, 1997; Bentler \& Yuan, 1999). The criteria showing the compatibility of the model and data set are given in the Table 5 below. The fact that the values in the fit indexes is close to 1 indicates that the fit between the data set and the model is very good, and zero represents the mismatch. In this study, the fit index values were close to 1 . This indicates that the operating model and the data set are compatible. 
Table 5. Conformity Indexes

\begin{tabular}{|c|c|c|}
\hline Fit indexes & $\begin{array}{c}\text { Model } \\
\text { Value }\end{array}$ & Fit Criterion \\
\hline RMSEA & 0.085 & $0.00 \leq \mathrm{RMSEA} \leq 0.10$ \\
\hline $\mathrm{X}^{2} / s d$ & 2.99 & $0 \leq \mathrm{X}^{2} / s d \leq 5$ \\
\hline GFI & 0.90 & $0.90 \leq \mathrm{GFI} \leq 1$ \\
\hline AGFI & 0.86 & $0.85 \leq \mathrm{AGFI} \leq 1$ \\
\hline NFI & 0.96 & $0.90 \leq \mathrm{NFI} \leq 1.00$ \\
\hline NNFI & 0.97 & $0.90 \leq \mathrm{NNFI}(\mathrm{TLI}) \leq 1.00$ \\
\hline RFI & 0.96 & $0.90 \leq \mathrm{RFI} \leq 1.00$ \\
\hline CFI & 0.98 & $0.90 \leq \mathrm{CFI} \leq 1.00$ \\
\hline IFI & 0.98 & $0.90 \leq \mathrm{IFI} \leq 1.00$ \\
\hline
\end{tabular}

Source: Original calculations.

\section{CONCLUSION}

The notion of time can bring both opportunities and constraints in achieving the hopes and expectations of individuals. The past experiences of individuals can be effective in their future decisions. The past, the present and the future are interrelated in various ways in understanding people's experiences and in project definitions for the future (Narotzky \& Besnier, 2014). Livelihood is one of the main concerns of individuals. The prospect of a better life, a higher welfare level triggers rural migration movements. Economic crises and uncertainty bring despair for the future.

Thefact that the resources and production opportunities existing in the country are not equal between regions causes development differences between regions. The settlements, where the industry and service sector are concentrated and developed, attract immigrants from rural areas by creating wage differences and new job opportunities. Individuals and society struggle to make life worth living. Economics also serves to make life worthwhile (Narotzky \& Besnier, 2014).

Unemployment is one of Turkey's fundamental problems. According to the latest data released by The Turkish Statistical Institute in the Turkey 15 and over age group at the number of unemployed increased by 980 thousand persons in the period of August 2019 compared to the same period last year was 4 million 650 thousand people. The unemployment rate in the country was $14.0 \%$ (Anonymous, Labor Force Statistics, August 2019 Newsletter, 2019b). In the same period; The non-agricultural unemployment rate was estimated at $16.7 \%$, up 3.5 percentage points. One of the problems caused by unemployment is immigration.
The study measured the Request and Action of Migration using Structural Equation Modeling with a sample of individuals living in rural area of central district of Erzincan. Migration Request and Action were studied with two observed variables. As a longterm and emotional desire, "MT - Would you like to migrate to the city center or another city?" according to the results of Structural Equation Modeling $(\gamma=0.97$ and $t=22.16)$. It is clear that MT is not affected by the economic and political conjuncture. The economic and political conjuncture was highly influential, and "MI - I am thinking of migrating from the village now." Structural model result was found as $(\gamma=-0.92$ and $t=$ -20.01). All parameters (latent variables) in the model have a negative effect on this result. In other words, the parameters of Economic Expectation, Hope and Social Capital have a linear effect on the decision of celestial action of individuals. When these three variables are positive, the decision of migration is also positive, and when these variables are negative, the migration is negative.

The Economic Expectation Variable (EE) was found to have a very strong negative impact on the decision of migration and the desire to migrate $(\gamma=-0.99 ; \mathrm{t}=$ -17.87). This variable demonstrates the reasons for an economic-based migration, such as finding a job, earning high income and increasing welfare. Findings show that individuals cannot meet their economic expectations in the cities they will migrate. The Turkish Statistical Institute estimates that non-agricultural unemployment rate increased by 3.5 percentage points to 16.7\% in August 2019 (Anonymous, 2019b). In this case, those who migrate from rural to urban employment may not be able to find a job. Again, the relative gap between rural income and urban income has been closing in recent years. The average wage in the agricultural sector in 2018 is 2113 (Turkish Lira) TRY (Anonymous, 2019c). The minimum gross wage in the same period is 2029.50 TRY (Anonymous, 2019d). Rural wage is higher than the minimum wage paid to unskilled workers in urban centers. As such (ceteris paribus) migration increases if urban wages increase or if the employment rate of cities increases (Todaro, 1969; Harris \& Todaro, 1970). Again, if urban wages are less than rural wages (ceteris paribus), reverse migration starts from cities to rural areas.

Individuals act according to the rational convictions in their minds about the future economic situation when making a migration decision to leave or return. Bad news about the general economic situation and 
unemployment in the future are more impressive than good news, and migration flows are affected. If the economic situation at the target location and the individual's expectations match, the decision is made for migration (Kahneman \& Tversky, 1979). The preferences of individuals can be reversed due to framing the results as gain or loss (Tversky \& Kahneman, 1991). If the economic situation deteriorates in the country, the possibility of not finding a job that decreases from $95 \%$ to $90 \%$ or finding a job that increases from $5 \%$ to $10 \%$ according to the possibility of finding a job or protecting the current job is framed and perceived negatively. The increasing unemployment rate in the country stopped and even reversed rural migration.

Hope (PE) variable has a very strong negative effect on individuals' migration decision and desire to migrate $(\gamma=-0.96 ; \mathrm{t}=-13.66)$. It is important in social, cultural and political conditions as well as economic conditions in individuals' decisions to migrate. The system model includes dynamic and spatial processes. In the researches, it was claimed that economic factors such as wages as well as non-economic factors were effective in the migration decisions of individuals (Deller et al., 2001; Oehmke et al., 2007; Michaelides, 2011; Hotchkiss \& Rupasingha, 2018). These non-economic factors include social and cultural opportunities, environmental quality and quality of life. In this study, Hope variable includes ideal living conditions and happiness factors. The findings show that rural people can not get better living conditions and happiness by migrating to the city.

Social Capital (SC) variable has a negatively moderate effect on individuals' decision to immigrate and desire to migrate $(\gamma=-0.48 ; \mathrm{t}=-8.19)$. Evidence has been found that local social capital based on receiving assistance from relatives, neighbors and friends is preventing external migration (Kan, 2007). Again, individuals with strong family ties were found to be more reluctant to migrate (Alesina \& Giuliano, 2011; Alesina et al., 2015). Individuals with a high level of social capital are generally less likely to migrate. At the social level, social capital has been shown to be an important factor in the overall migration decision (Hotchkiss \& Rupasingha, 2018).

Finally, the findings of the study reveal that the economic and social conjuncture is not suitable for migration. Migrating to the great sheriffs is not attractive to rural agricultural workers. Migration is no longer a hope for a better future. In recent years, the migration movement from large cities to rural settlements has started (Anonymous, 2019e). This shows that immigrant behavior is rational and appropriate to economic theories.

\section{REFERENCES}

- ADLER, P. S., \& KWON, S. W. (2002). Social Capital: Prospects For a New Concept. Academy of, 27(1), 17-40.

- AlesinA, A., \& GIUliAnO, P. (2011). Family Ties and Political Participation. Journal of the European Economic Association, 9(5), 817839.

- AlesinA, A., ALGAN, Y., CAHUC, P., \& GIULIANO, P. (2015). Family Values and The Regulation of Labor. Journal of the European Economic Association, 13(4), 599-630.

- ANONYMOUS. (2018a, Novenber 30). Provincial / District Centers and Town / Village Population, General Population Censuses by Years and Gender ADNKS,. tuik: http://www.tuik.gov.tr/UstMenu. do?metod=temelist adresinden alınd 1

- ANONYMOUS. (2019b, December 15). Labor Force Statistics, August 2019 Newsletter. tuik: http://www.tuik.gov.tr/PreTablo.do?alt_ id=1007 adresinden alındı

- ANONYMOUS. (2019c, December 12). Agricultural Holdings Labour Wage Structure. tuik: http://www.tuik.gov.tr/UstMenu. do?metod=temelist. adresinden alınd 1

- ANONYMOUS. (2019d, December 15). Minimum wage. tuik: https: / / www.ailevecalisma.gov.tr/istatistikler/calisma-hayatiistatistikleri/asgari-ucret/asgari-ucret-2019/ adresinden alındı

- ANONYMOUS. (2019e, December 18). Migration, Net Migration and Net Migration Rate of Provinces, General Population Censuses - ABPRS. tuik: http://www.tuik.gov.tr/UstMenu.do?metod=temelist adresinden alınd 1

- BALCIOĞLU, I. (2007). Migration in Social and Psychological Terms. Bilge Publishing.

- BENTLER, P. M., \& YUAN, K. H. (1999). Structural Equation Modeling With Small Samples: Test Statistics. Multivariate Behavioral Research, 34(2), 181-197.

- BIÇKI, D. (2011). Buıldıng The Future in City: Migratıon Trends in Canakkale Rural. Süleyman Demirel University Journal of the Faculty of Economics and Administrative Sciences, 16(3), 149-169.

- BOURDIEU, P. (1989). Social Space and Symbolic Power. Sociological Theory, 7(1), 14-25.

- BOURDIEU, P., \& WACQUANT, L. J. (1992). An invitation to Reflexive Sociology. Chicago: University of Chicago press.

- CHEUNG, G. W., \& RENSVOLD, R. B. (2002). Evaluating Goodnessof-fit Indexes for Testing Measurement invariance. Structural Equation Modeling, 9(2), 233-255.

- COLEMAN, J. S. (1988). Social Capital in the Creation of Human Capital. American Journal of Sociology (94), 95-120.

- CRAWFORD, T. J. (1973). Beliefs About Birth Control: A Consistency Theory Analysis. Representative Research in Social Psychology, 4(1), 53.

- CZAIKA, M. (2015). Migration and Economic Prospects. Journal of Ethnic and Migration Studies, 41(1), 58-82.

- DAVID, Q. J. (2010). Local Social Capital and Geographical Mobility. Journal of Urban Economics, 68(2), 191-204.

- DELLER, S., TSUNG-HSIU, T., MARCOUILLER, D.W., ENGLISH, D.B.K. (2001). The Role of Amenities and Quality of Life in Rural Economic Growth. Am. J. Agric. Econ, 352.

- ESSES, V. M., HODSON, G., \& DOVIDIO, J. F. (2003). Public Attitudes Toward Immigrants and Immigration: Determinants and Policy Implications. 
- ESSES, V. M., JACKSON, L. M., \& BENNETT-ABUAYYASH, C. (2010). Intergroup competition. The Sage Handbook of Prejudice, Stereotyping and Discrimination, 1, 225-240.

- HAGEN-ZANKER, J. (2008). Why Do People Migrate? A Review Of The Theoretical Literature. A Review Of The Theoretical Literature (January 2008). Maastrcht Graduate School of Governance Working Paper No.

- HARRIS, J. R., \& TODARO, M. P. (1970). Migration, Unemployment and Development: a two-sector analysis. The American economic review, 60(1), 126-142.

- HERSHBERGER, S. L. (2003). The Growth of Structural Equation Modeling: 1994-2001. Structural Equation Modeling, 10(1), 35-46.

- HOTCHKISS, J. L., \& RUPASINGHA, A. (2018). Individual Social Capital and Migration. Workıng Paper Serıes, Federal Reserve Bank of Atlanta.

- HOYLE, R. (1995). Structural Equation Modeling: Concepts, İssues, and Applications. I. R. (Ed.) içinde, The structural Equation Modeling Approach. Thousand Oaks, CA: Sage.: Structural Equation Modeling: Concepts, Issues and Applications.

- ILHAN, M., \& CETİN, B. (2014). Comparing the analysis Results Of The Structural Equation Models (SEM) Conducted Using LISREL and AMOS. Journal Of Measurement and Evaluation In Education and Psychology-Epod, 5(2), 26-42.

- JÖRESKOG, K. G., \& SÖRBOM, D. (1993). LISREL 8: Structural Equation Modeling with the SIMPLIS Command Language. Scientific Software International.

- KAHN, J. H. (2006). Factor Analysis in Counseling Psychology Research, Training, and Practice: Principles, Advances, and Applications. The Counseling Psychologist, 34(5), 684-718.

- KAHNEMAN, D., \& TVERSKY, A. (1979). Prospect Theory: An Analysis of Decision Under Risk. Econometrica, 47(2), 363-391.

- KAHNEMAN, D., KNETSCH, J. L., \& THALER, R. H. (1991). Anomalies: The Endowment effect, Loss Aversion, and Status Quo Bias. Journal of Economic Perspectives, 5(1), 193-206.

- KAN, K. (2007). Residential Mobility and Social Capital. Journal of Urban Economics, 61(3), 436-457.

- KATZ, E., \& STARK, O. (1986). Labor Migration and Risk Aversion in Less Developed Countries. Journal of Labor Economics, 4(1), 134149.

- LEECH, N. L., BARRETT, K. C., MORGAN, G. A., CLAY, J. N., \& QUICK, D. (2005). SPSS for Intermediate Statistics: Use and Interpretation. (N. L. Mahwah, Dü.)

- LEWIS, W. A. (1954). Economic Development With Unlimited Supplies of Labour. The Manchester School, 22(2), 139-191.

- LOMAX, R. G., \& SCHUMACKER, R. E. (2004). A Beginner's Guide To Structural Equation Modeling. Psychology Press.

- MABOGUNJE, A. L. (1970). Systems Approach to A Theory of Rural-Urban Migration. Geographical Analysis, 2(1), 1-18.

- MASSEY, D. S. (1990). Social Structure, Household Strategies, and the Cumulative Causation of Migration. Population Index, 3-26.

- MASSEY, D. S., ARANGO, J., HUGO, G., KOUAOUCI, A., \& PELLEGRINO, A. (1999). Worlds in Motion: Understanding International Migration at the End of the Millennium: Understanding International Migration at the End of the Millennium. Clarendon Press.

- MASSEY, D. S., ARANGO, J., HUGO, G., KOUAOUCI, A., PELLEGRINO, A., \& TAYLOR, J. E. (1993). Theories of International Migration: A Review and Appraisal. Population and Development Review, 19(3), 431-466.

- MASSEY, D. S., ARANGO, J., HUGO, G., KOUAOUCI, A., PELLEGRINO, A., \& TAYLOR, J. E. (1993). Theories of International Migration: A Review and Appraisal. Population and Development Review, 19(3), 431-466.

- MERCER, J. (2005). Prospect theory and political science. Annu. Rev.
Polit. Sci., 8, 1-21.

- MiCHAELIDES, M. (2011). The effect of local ties, wages, and housing costs on migration decisions. The Journal of Socio-Economics, 40(2), 132-140.

- NAROTZKY, S., \& BESNIER, N. (2014). Crisis, Value, and Hope: Rethinking The Economy: An Introduction to Supplement 9. Current Anthropology, 55(9), 4-16.

- OEHMKE, J. F., TSUKAMOTO, S., \& POST, L. A. (2007). Can Health Care Services Attract Retirees and Contribute to The Economic Sustainability of Rural Places? Agricultural and Resource Economics Review, 36(1), 95-106.

- PALlONI, A., MASSEY, D. S., CEBALlOS, M., ESPINOSA, K., \& SPITTEL, M. (2001). Social Capital And İnternational Migration: A Test Using Information on Family Networks. American Journal of Sociology, 106(5), 1262-1298.

- PEDHAZUR, E. J. (1997). Multiple Regression in Behavioral Research: Explanation and Prediction. Inc: New York, NY.: Thompson Learning.

- PETERSEN, W. (1958). A general typology of migration. American Sociological Review, 23(3), 256-266.

- PITUCH, K. A., \& STEVENS, J. P. (2009). Applied Multivariate Statistics For The Social Sciences. 21. New York and London: Routledge.

- RANIS, G., \& FEI, J. C. (1961). A Theory of Economic Development. The American economic review, 533-565.

- RAYKOV, T., \& MARCOULIDES, G. A. (2006). On Multilevel Model Reliability Estimation From The Perspective of Structural Equation Modeling. Structural Equation Modeling, 13(1), 130-141.

- SAHOTA, G. S. (1968). An Economic Analysis of Internal Migration in Brazil. Journal of political economy, 66(2), 218-245.

- SIMON, H. A. (1983). Reason in Human Affairs. Stanford University Press.

- SJAASTAD, L. A. (1962). The Costs and Returns of Human Migration. Journal of political Economy, 70(5,Part 2), 80-93.

- SPILIMBERGO, A., \& UBEDA, L. (2004). Family Attachment And The Decision to Move By Race. Journal of Urban Economics, 55(3). 478-497

- TABACHNICK, B. G., FIDELL, L. S., \& ULLMAN, J. B. (2007). Using Multivariate Statistics (Cilt Vol.5). Boston: MA: Pearson.

- THALER, R. (1980). Toward A Positive Theory of Consumer Choice. Journal of Economic Behavior \& Organization, 1(1), 39-60.

- TODARO, M. P. (1969). A Model of Labor Migration And Urban Unemployment in Less Developed Countries. The American Economic review, 59(1), 138-148.

- TVERSKY, A., \& KAHNEMAN, D. (1991). Loss Aversion in Riskless Choice: A Reference-Dependent Model. The Quarterly Journal of Economics, 106(4), 1039-1061.

- WESTON, R., \& Gore Jr, P. A. (2006). A Brief Guide To Structural Equation Modeling. The Counseling Psychologist, 34(5), 719-751.

- YAMANE, T. (1967). Statistics: An introductory Analysis. New York: Harper and Row.

- ZAFER, A. (2016). The Concept of "Culture" As A Key For Migratıon Studies. University Of Uludag / Journal of Social Sciences, Journal of Social Sciences, 19(30). 